\title{
J.R.R. TOLKIEN ON FAËRIE AND FAËRIE-STORIES ${ }^{1}$
}

\author{
Paul E. MiCHELSON \\ Huntington University
}

\begin{abstract}
The paper sums up J.R.R. Tolkien's ideas related to Faërie and Faërie-stories as elaborated in his influential lecture and essay "On Fairy-stories.”
\end{abstract}

Keywords: J.R.R. Tolkien, Faërie, Faërie-stories, Eucatastrophe, subcreation

\section{Introduction}

Forty-five years ago, when J.R.R. Tolkien (1892-1973) took his final journey into the True West, his revolutionary views on Faërie were relatively unknown, even though they had been clearly set forth in his seminal 1939 St. Andrew's University Andrew Lang Lecture "Fairy Stories" and, subsequently expanded and published in 1947 and 1964 as his now-classic essay "On Fairy-Stories."” The purpose of this paper is fairly straightforward: to provide a précis or summing-up of Tolkien's ideas concerning Faërie and Faërie-stories-that is, stories about Faërie.

\section{The Texts}

The textual history of Tolkien's essay from 1939 to the present is not long, but is a trifle complex.

\footnotetext{
1 A lecture prepared for the 2018 Interdisciplinary Conference on C.S. Lewis and Kindred Spirits, Al. I. Cuza University, Iaşi, Romania, November 22, 2018. A somewhat abbreviated version was presented at the First C.S. Lewis and Kindred Spirits Symposium, Universitatea Divitia Gratiae, Chișinău, Moldova, February 20, 2018.

2. For a discussion, see Michelson 2012, Michelson 2014, and Tolkien, Fairy-stories, 2008, p. $161 \mathrm{ff}$.
} 
1. J.R.R. Tolkien, "Fairy Stories," delivered as the $12^{\text {th }}$ Annual Andrew Lang Lecture, St. Andrews University, Scotland, March 8, 1939. The complete original text of the 1939 lecture is not extant, and some of what Tolkien actually said at St. Andrews has to be reconstructed from 1939 newspaper reports and manuscript fragments. This was expertly done in 2005 by Verlyn Flieger and Douglas Anderson (Tolkien, Fairy-stories, 2008)

2. J.R.R. Tolkien, “On Fairy-stories,” in C.S. Lewis, ed., Essays presented to Charles Williams (London: Oxford University Press, 1947), pp. 38-89. This was the first published version and was a muchexpanded exploration of Tolkien's 1939 ideas.

3. J.R.R. Tolkien, “On Fairy-stories," in J.R.R. Tolkien, Tree and Leaf (London: George Allen and Unwin, 1964), pp. 11-70. Tolkien misleadingly described this as being "reproduced with only a few minor alterations" from the 1947 version, but was actually a considerably revised, second edition. This publication unfortunately linked the essay with Tolkien's semi-autobiographical allegory "Leaf by Niggle," which many thereafter have erroneously taken to be a reflection of the ideas set forth in "On Fairy-stories." In fact, that task was undertaken by Tolkien in his short story Smith of Wootton Major (1967) (Tolkien, Smith of Wootton Major, 2005). Flieger's edition of Smith was accompanied by another Tolkien essay, also entitled "Smith of Wootton Major," which provides an abbreviated take on Faërie (Tolkien, Smith of Wootton Major, 2005, 84-101); a third version of Tolkien's ideas also written in the 1960s as a draft preface to a never-published re-edition of George MacDonald's The Golden Key. (Tolkien, Smith of Wootton Major, 2005, pp. 71-75)

4. "On Fairy-stories" was reprinted in J.R.R. Tolkien, The Tolkien Reader (New York: Ballantine Books, 1966), pp. 3-84, which became the most widely circulated version of Tolkien's essay. This version was hastily cobbled together to capitalize on Tolkien's meteoric rise to fame, especially in America, with the paperback publication of The Lord of the Rings. Readers wanted more Hobbit and were offered the professor's theories about Faërie-stories. Regrettably, this edition was seriously marred by a number of typographical errors. The volume oddly repaginated each of the sections (this was changed in subsequent reprintings) which were simply a composite of previously published works, The Homecoming of Beorhtnoth Beorhthelm's Son (1953), Tree and Leaf (1964), Farmer Giles of Ham (1949), and The Adventures of Tom Bombadil (1962), along with a "Publisher's Note," pp. vii-viii, and an introduction, "Tolkien's Magic Ring," pp. ix-xvi, by Peter S. Beagle, which had nothing to do with the contents of the Reader.

5. J.R.R. Tolkien, "On Fairy-stories," in J.R.R. Tolkien, The Monsters and the Critics and Other Essays, edited with a foreword by Christopher Tolkien (London: George Allen and Unwin, 1983), pp. 109-161, a very good edition 
with minor corrections by Tolkien's son that made the essay more widely available.

6. J.R.R. Tolkien, Tree and Leaf including the poem Mythopoeia, second edition with an introduction by Christopher Tolkien (London: Unwin Hyman, 1988), pp. 9-73, which was important for publishing for the first time the full text of an essential poem referred to in Tolkien's essay. ${ }^{3}$

7. J.R.R. Tolkien, Tolkien on Fairy-stories, expanded edition with commentary and notes by Verlyn Flieger and Douglas A. Anderson (London: HarperCollins, 2008). This is the critical edition which sorts out all of the above.

8. And, finally, there was J.R.R. Tolkien, Tales of the Perilous Realm, with introduction by Tom Shippey, and illustrations and an afterword by Alan Lee (Boston: Houghton Mifflin Harcourt, 2008), which included Tolkien's stories and poems "Roverandom," "Farmer Giles of Ham," "The Adventures of Tom Bombadil," "Smith of Wootton Major," and "Leaf by Niggle," capped off with the "On Fairy-stories" essay as an appendix. This edition has the merit of bringing together for the first time the final form of Tolkien's essay and its fictional working out in Tolkien's Smith. Its one shortcoming is that it did not include Tolkien’s “Mythopoeia” poem.

\section{Of Faërie and Faërie-Stories}

Verlyn Flieger and Douglas Anderson argue that Faërie is "Possibly the single most important term in Tolkien's critical lexicon...” (Tolkien, Fairy-stories 2008, p. 85) ${ }^{4}$. And yet the meaning of Faërie (and Faërie-stories) remains somewhat elusive, despite the efforts of Christopher Tolkien, Tom Shippey, Flieger and Anderson, and others. ${ }^{5}$ This is perhaps due to the very nature of Faërie itself. Tolkien, indeed, warned us that

Faërie is a perilous land, and in it are pitfalls for the unwary and dungeons for the overbold....The realm of fairy-story is wide and deep and high and filled

\footnotetext{
${ }^{3 .}$ On the poem, see Christopher Tolkien's "Preface," to Tolkien, Tree and Leaf, 1988, 6 ff. On myth and mythopoeia, or as C.S. Lewis called them, "lies...breathed through silver,” see Carpenter, 1979. 42-45; Duriez 45-59; Jacobs 142-150; and McGrath 55-81. The influence of the work of Owen Barfield on Tolkien and Lewis's thinking about myth through his book Poetic Diction (1928) cannot be overestimated. See Thorson 2015.

${ }^{4}$ Flieger Faërie, p. 35.

${ }^{5 .}$ Verlyn Flieger's work has been critical here, including Flieger 1997, Flieger 2012, Flieger 2017, and her contribution to the 2018 volume and catalogue for this year's Tolkien Exhibition at Oxford's Bodleian Library. I wish to note here my appreciation to my niece, Lisa Michelson, for providing me with a copy of this handsome work. For Shippey's indispensable work, see Shippey, 2003 and Shippey 2000.
} 
with many things: all manner of beasts and birds are found there; shoreless seas and stars uncounted; beauty that is an enchantment, and an ever-present peril; both joy and sorrow as sharp as swords. In that realm a man may, perhaps, count himself fortunate to have wandered, but its very richness and strangeness tie the tongue of a traveller who would report them. And while he is there it is dangerous for him to ask too many questions, lest the gates should be shut and the keys be lost. (Tolkien, “On Fairy-stories”, p. 27) ${ }^{6}$

It is an unmistakable fact that Faërie must be approached indirectly because, as George MacDonald wrote elsewhere, “analysis is death, not life.” (Michelson, "MacDonald and Tolkien" 93) Both Tolkien and MacDonald agreed that in cases such as this to define too much is to destroy.

In addition, Tolkien's radical views remained partially obscured by the obtuseness of $20^{\text {th }}$ century Western society and culture, which ridiculed fantasy literature in general and Tolkien's Middle-earth in particular as escapist, sexist, juvenile trash, and what have you. For the modern critical view, one need look no further than the noted critic Edmund Wilson's 1956 response to The Lord of the Rings, which was entitled “Oo, Those Awful Orcs!” (Wilson, pp. 55-63) Wilson claimed to have read the book to his seven-year old child and derided it as "a children's book which has somehow got out of hand....Dr. [sic] Tolkien has little skill at narrative and no instinct for literary form....the poverty of invention displayed...is, it seems to me, almost pathetic....An impotence of imagination seems to me to sap the whole story." No word on whether his sevenyear old agreed with this critique.

Far fewer at the time were those who were actually receptive to real stories about Faërie, such as C.S. Lewis, who wrote:

This book is like lightning from a clear sky; as sharply different, as unpredictable in our age as Songs of Innocence were in theirs....Probably no book yet written in the world is quite such a radical instance of what its author has elsewhere called 'sub-creation'...here are beauties which pierce like swords or burn like cold iron; here is a book that will break your heart....we know at once that it has done things to us. We are not quite the same men. And though we must ration ourselves in our re-readings, I have little doubt that the book will soon take its place among the indispensables.” (Lewis, On Stories, pp. 83-84, 90) ${ }^{7}$

${ }^{6}$ Tolkien's essay is hereafter cited as Tolkien, “On Fairy-stories,” using Flieger and Anderson as the definitive text.) Cf. Flieger, "Pitfalls in Faërie," in Flieger 1997, pp. 227-253.

${ }^{7}$ Cf. in the same volume, pp. 81-82, Lewis's prescient 1937 Times Literary Supplement review of The Hobbit, which concluded "Prediction is dangerous: but The Hobbit may well prove a classic.” No kidding. 
Today, perhaps, the tide has shifted, and most of us laugh at the Edmund Wilsons and their ilk who simply don't get it and find ourselves agreeing with C.S. Lewis, who declared that

Nothing quite like it was ever done before... The utterly new achievement of Professor Tolkien is that... [he has built up a] sense of reality unaided...[creating a myth that] points for each reader to the realm he lives in most. It is a master key; use it on what door you like....The value of the myth is that it takes all the things we know and restores to them the rich significance which has been hidden by 'the veil of familiarity'." (On Stories pp. 83-85, 90)

The importance of Faërie in Tolkien's thought should, therefore, be obvious. It is also clear that a grasp of what Tolkien is talking about with regard to Faërie and Faërie-stories is of prime importance for an appreciation of his writings.

However, before proceeding further, two very important stipulations need to be made. Firstly, Tolkien took great pains to distance himself from prevalent ideas of the late $19^{\text {th }}$ and $20^{\text {th }}$ centuries (and extending into our Disnified $21^{\text {st }}$ century) concerning fairies as diminutive, delicate winged creatures. Tolkien despised Disney possibly because Tinker-bell was the very antithesis of Faërie as seen in Spencer's epic Fairy Queen, terrible to behold and awesome in power. $^{8}$

Secondly, it would have been helpful if Tolkien had consistently used "Faërie" to refer to "the Perilous Realm," that is, to accounts of Secondary worlds and "sub-creation," to stories of Fantasy, Recovery, Escape, and Consolation, and to tales of the Eucatastrophe. What follows tries to affirm that consistency, which emerged in Tolkien's last writings. In the end, I hope that we can agree to use Faërie, italicized with a capital "F", and Faërie-stories, with a hyphen, to maintain appropriate clarity about Tolkien's vision and ideas.

This remainder of this paper will respond to three of the questions raised by Tolkien in his essay "On Fairy-stories": 1. "What is Faërie?” 2. "What are Faërie and Faërie-stories not?" And lastly, 3. "What is the use of Faërie and Faërie-stories?” There are, of course, other issues dealt with by Tolkien's essay which need not concern us here, including such matters as the emergence of Faërie out of what Tolkien called the Pot of Soup or Cauldron of Story;

\footnotetext{
${ }^{8}$ On Tolkien and Disney, see J.R.R. Tolkien to C. A. Furth of Allen and Unwin, May 13, 1937 (Tolkien, Letters, p. 17), responding to a proposed American edition of The Hobbit that his only reservation on the art work would be "to veto anything from or influenced by the Disney studios (for all whose works I have a heartfelt loathing)." And in regard to a German edition, J.R.R. Tolkien wrote to Stanley Unwin, December 7, 1946, in (Tolkien, Letters, p. 119): "He has sent me some illustrations...which despite certain merits, such as one would expect of a German, are I fear too 'Disnified' for my taste...”
} 
(Tolkien, “On Fairy-stories”, p. 38 ff; Michelson, "Development”, p. 119) the three "Faces of Faërie" ("the Mystical towards the Supernatural, the Magical towards Nature; and the Mirror of Scorn and pity towards man") (Tolkien, "On Fairy-stories”, p. 44ff.; Michelson, "Development," pp. 117-118), the meaning of such stories (Tolkien, "On Fairy-stories", p. 58 ff; Michelson, "MacDonald and Tolkien", pp. 94-96), ${ }^{9}$ and the hostility of Faërie to drama. (Tolkien, "On Fairy-stories", pp. 61-63, 112; as well as Flieger, "Faërie”, pp. 40-43, on "Faërian Drama.")

\section{What is Faërie?}

We begin with the question “What is Faërie?” First of all, Faërie is a place, the Perilous Realm, a Secondary world that differs from the Primary world in which we live in that it is the product of what Tolkien called "sub-creation." In Tolkien's words,

Faërie contains many things besides elves and fays, and besides dwarfs, witches, trolls, giants, or dragons: it holds seas, the sun, the moon, the sky; and the earth, and all things that are in it: tree and bird, water and stone, wine and bread, and ourselves, mortal men, when we are enchanted."

(“On Fairy-stories”, p. 32)

And what, then, are "Faërie-stories"? These are not usually about fairies as such, Tolkien tells us:

Stories that are actually concerned primarily with 'fairies'...are relatively rare, and as a rule not very interesting. Most good 'fairy-stories' are about the aventures (sic) ${ }^{10}$ of men in the Perilous Realm or upon its shadowy marshes....The definition of a fairy-story...does not depend on any definition or historical account of elf or fairy, but upon the nature of Faërie: the Perilous Realm itself, and the air that blows in that country.

(“On Fairy-stories”, p. 32) ${ }^{11}$

But, Tolkien cautions us,

I will not attempt to define that, nor to describe it directly. It cannot be done. Faërie cannot be caught in a net of words; for it is one of its qualities to be

\footnotetext{
${ }^{9}$ This includes Tolkien's views on allegory.

${ }^{10}$ See Flieger and Anderson, Tolkien on Fairy-stories, 2008, pp. 93 ff.: “Tolkien chooses the French aventures, which conveys in addition to the usual meaning of 'exciting experiences', the darker implications of hazard, uncertainty and outright danger that his following phrase 'the Perilous Realm' underscores.”

11. Compare Flieger, "Faërie,” 36, for the philology and etymology involved.
} 
indescribable, though not imperceptible. It has many ingredients, but analysis will not necessarily discover the secret of the whole....For the moment I will say only this: a 'fairy-story' is one which touches on or uses Faërie, whatever its own main purpose may be: satire, adventure, morality, fantasy. Faërie itself...is magic of a peculiar mood and power, at the furthest pole from the vulgar devices of the laborious, scientific, magician.

(“On Fairy-stories”, pp. 32-33) ${ }^{12}$

The difficulty, as Verlyn Flieger has noted, is that in Tolkien’s thinking Faërie is

a unified concept unsusceptible to dissection. One has the sense that he knew better what he meant than how to say it....He was a traveller reporting to an audience that did not believe in fairies, let alone Faërie....Tolkien found Faërie a hard sell to a world that favoured realism over enchantment, preferred motorcars to dragons, and measured time in seconds instead of experience.

(Flieger, "Faërie”, p. 35)

And what are the "Secondary worlds" in which Faërie-stories exist? W. H. Auden summarized this well in his "Afterword" to the 1967 re-edition of George MacDonald's The Golden Key:

Every normal human being is interested in two kinds of worlds: the Primary, everyday, world which he knows through his senses, and a Secondary world or worlds which he not only can create in his imagination, but also cannot stop himself creating. A person incapable of imagining another world would be subhuman, and a person who identifies his imaginary world with the world of sensory fact has become insane. (Auden, pp. 81-82) ${ }^{13}$

Thus, the Secondary world is like the Primary world, but somehow different. ${ }^{14}$ This is explained in a dialogue from George MacDonald’s 1895 novel Lilith:

12 This recalls the comments of C.S. Lewis on Magic, the Magicians's Bargain of Science, and Christianity: "You will even find people who write about the sixteenth century as if Magic were a medieval survival and Science the new thing that came to sweep it away. Those who have studied the period know better. There was very little magic in the Middle Ages: the sixteenth and seventeenth centuries are the high noon of magic. The serious magical endeavor and the serious scientific endeavor are twins...born of the same impulse.” (Lewis, Abolition, pp. 76-77). Compare Lewis, English Literature, p. $5 \mathrm{ff}$.

13 This, ironically, was the re-edition that beat Tolkien's own projected version for Pantheon Books to the market, which had to be abandoned as a result.

${ }^{14}$ In "Smith of Wootton Major," Tolkien wrote "The geographical relations of Wootton and Faery are inevitably, but also intentionally left vague... it is necessary that Faery and the World (of Men), though in contact, should occupy a different time and space, or occupy them in different modes." On the other hand, "Faery is a vast world in its own 
Mr. Raven: "There is in your house a door, one step through which carries me into a world very much another than this."

Vane: “A better?"

Mr. Raven: "Not throughout; but so much another that most of its physical, and many of its mental laws are different from those of this world. As for moral laws, they must everywhere be fundamentally the same.” (MacDonald, p. 40) ${ }^{15}$

Different, but morally the same. Compare this with the dialogue in Tolkien's The Lord of the Rings and then with a few lines from his poem, "Mythopoeia." First the dialogue:

Eomer: It is hard to be sure of anything among so many marvels. The world is all grown strange... How shall a man judge what to do in such times?

Aragorn: As he ever has judged. Good and ill have not changed since yesteryear; nor are they one thing among Elves and Dwarves and another among Men. It is a man's part to discern them, as much in the Golden Wood as in his own house.

(Tolkien, The Lord of the Rings, pp. 427-428)

And from "Mythopoeia”:

Though all the crannies of the world we filled with elves and goblins, though we dared to build gods and their houses out of dark and light, and sowed the seed of dragons_-'twas our right (used or misused). That right has not decayed. We make still by the law in which we're made. (Tolkien, Tree and Leaf, p. 99) ${ }^{16}$

Faërie is also a world in which "the Magical" is "the essential centre' of the Secondary World (Tolkien, "Manuscript A,” in Tolkien, “On Fairy-stories”, p. 183); or as Tolkien put it in "On Fairy-stories": "The essential face of Faërie is...the Magical.” (Tolkien, “On Fairy-stories”, p. 44) He elaborates:

Anyone inheriting the fantastic device of human language can say the green sun...To make a Secondary World inside which the green sun will be credible,

right, that does not depend for its existence upon Men, and which is not primarily nor indeed principally concerned with Men.” (Tolkien, “Smith of Wootton Major”, p. 85, 93) This previously unpublished essay was first published by Verlyn Flieger in her edition of Smith. The essay provides an illuminating and unique direct discussion by Tolkien of his art.

${ }^{15}$ I owe this reference to Prickett, Victorian Fantasy, p. 162.

${ }^{16}$ Cited also in Tolkien, “On Fairy-stories”, p. 65. On "pluralism” and relativism, see Prickett, Narrative, Religion, p. 1 ff. 
commanding Secondary Belief, will probably require labour and thought, and will certainly demand a special skill, a kind of elvish craft. Few attempt such difficult tasks. But when they are attempted and in any degree accomplished then we have a rare achievement of Art: indeed narrative art, story-making in its primary and most potent mode." (Tolkien, "On Fairy-stories”, p. 61) The goal is "The achievement of...'the inner consistency of reality" with Art as "the operative link between Imagination and the final result, Sub-creation....

(Tolkien, “On Fairy-stories”, p. 59) ${ }^{17}$

Quoting Auden once more on Faërie:

The Secondary worlds of myth and fairy tale, however different from the Primary world, presupposes its reality. As Professor Tolkien has said: 'If men could not distinguish between men and frogs, stories about frog kings would not have arisen. A Secondary world may be full of extraordinary beings...and extraordinary objects...but like the Primary world, it must, if it is to carry conviction, seem to be a world governed by laws, not by pure chance...”

(Auden, pp. 82-83)

The ideas of "Sub-creator" and "Sub Creation" are-after Faërie-the most important part of Tolkien's ideas concerning art and the artistic process. And, as Flieger and Anderson argue, for Tolkien, “...the Prime Creator is God. His creation is the world of humankind, who following in God's creative footsteps, both make and are made in God's image.” (“On Fairy-stories”, pp. 102-103) ${ }^{18}$

\section{What are Faërie and Faërie-stories not?}

The second problem addressed by Tolkien in his lecture is "What are Faërie and Faërie-stories not?" This need not detain us here very long. (See Tolkien, "On Fairy-stories”, p. 29 ff, p. 49 ff.; Michelson, "Development”, p. 117) Tolkien debunks the idea that Faërie-stories are about beings of diminutive size; they are not. ( "On Fairy-stories", pp. 29-30.) He refutes the idea that Faërie-stories are just about fairies; they usually are not. ( "On Fairy-stories”, pp. 31-32) Nor are Faërie-stories folk stories (such as Charles Perrault's Contes or Grimm's Fairy Tales), travellers' tales (such as Gulliver's Travels or Baron Munchausen), dream stories (such as Alice in Wonderland), or beast fables (such as The Monkey's Heart or The Wind in the Willows). ("On Fairy-stories", pp. 33-37)

Lastly, in this defining by negation, Faërie-stories are not necessarily written for children, an idea common in modern times, but no more than the

${ }^{17}$ Cp. Flieger, Green Suns and Faërie.

${ }^{18}$ Compare Sayers (1956); Keating (2006); Pezzini (2018), Kilby (2016), The Arts, pp. 12-105; 106-133; Kilby, Well of Wonder, pp. 241-253; Purtill (2003); and Caldecott (2012). 
product of "an accident of our domestic history." ( "On Fairy-stories”, pp. 4959) ${ }^{19}$ Readers of such stories "may have children's hearts...but they have also heads.” (Tolkien, "Manuscript A," in Tolkien, “On Fairy-stories”, pp. 185-188) In an anecdote he wrote for the revision of his essay that was omitted when it went to print, Tolkien tells us:

I once received a salutary lesson. I was walking in a garden with a small child... I said like a fool: "Who lives in that flower?" Sheer insincerity on my part. 'No one,' replied the child. 'There are Stamens and a Pistil in there.' He would have liked to tell me more about it, but my obvious and quite unnecessary surprise had shown too plainly that I was stupid so he did not bother and walked away."

(Tolkien, “Manuscript B,” in Tolkien, “On Fairy-stories”, p. 248)

Children are not to be lightly patronized. By the time Tolkien completed The Lord of the Rings, he wrote that he had "freed" himself "from the contemporary delusions about 'fairy-stories;' and children... The Lord of the Rings ... was a practical demonstration... It was not written 'for children', or for any kind of person in particular, but for itself.” (Tolkien, Letters, pp. 309-310) ${ }^{20}$

\section{What is the use of Faërie and Faërie-stories?}

The final question under consideration here concerns the function of Faëriestories: "What is the use of Faërie and Faërie-stories?" This question also suggests additional characteristics for Faërie and Faërie-stories. Tolkien wrote

If adults are to read fairy-stories as a natural branch of literature...what are the values and functions of this kind?... First of all, if written with art, the prime value of fairy-stories will simply be that value which, as literature, they share with other literary forms. But fairy-stories offer also, in a peculiar degree or mode, these things: Fantasy, Recovery, Escape, and Consolation...

(“On Fairy-stories”, pp. 58-59)

Let us consider briefly each of these in turn. Tolkien pointed out:

The human mind is capable of forming mental images of things not actually present. The faculty of conceiving the images is (or was) naturally called Imagination...The achievement of the expression, which gives (or seems to give) 'the inner consistency of reality', [that is: which commands or induces

${ }^{19}$ C.S. Lewis had a lot to say about this: see Lewis's essays "On Stories," "On Three Ways of Writing for Children," "Sometimes Fairy Stories May Say Best What's to Be Said," and “On Juvenile Tastes," all reprinted in Lewis, On Stories.

${ }^{20}$ J.R.R. Tolkien to Jane Neave, November 22, 1961. For a survey of how this worked out in Tolkien's own fiction, see Flieger, “Faërie”, pp. 36-40. 
Secondary Belief] is...Art, the operative link between Imagination and the final result, Sub-creation.

This is what Tolkien calls “Fantasy.” (“On Fairy-stories”, pp. 59-60) ${ }^{21}$

Fantasy, of course, starts out with an advantage: arresting strangeness... [However] Many people dislike being 'arrested'. They dislike any meddling with the Primary World, or such small glimpses of it as are familiar to them... We need a word for this elvish craft, but all the words that have been applied to it have been blurred and confused with other things. Magic is ready to hand...but Magic should be reserved for the operations of the Magician."

(“On Fairy-stories, pp. 63-64)

Tolkien opts to call this "Enchantment." It is the "sub-creative art which plays strange tricks with the world and all that is in it." ("On Fairy-stories”, pp. 64-65) In the words of the 1931 poem, “Mythopoeia,” which Tolkien wrote for the preChristian C.S. Lewis, Sub-creation is the process of

refracted light through

whom is splintered from a single White

to many hues, and endlessly combined

in living shapes that move from mind to mind. ${ }^{22}$

"Fantasy,” Tolkien concludes, “is a natural human activity. It certainly does not destroy or even insult Reason... Fantasy remains a human right: we make in our measure and in our derivative mode, because we are made: and not only made, but made in the image and likeness of a Maker.” (“On Fairy-stories”, pp. 65-66) In the end, "'Faery' is as necessary for the health and complete functioning of the Human as is sunlight for physical life...” (Tolkien, Smith of Wootton Major, p. 101)

A second use or function of Faërie-stories is Recovery, "(which includes return and renewal of health) [it] is a re-gaining-regaining of a clear view... We need ... to clean our windows; so that the things seen clearly may be freed

\footnotetext{
${ }^{21}$ The parenthetical phrase here is Tolkien's own expansion of "inner consistency of reality.” Compare Flieger and Anderson (Tolkien, “On Fairy-stories”, pp. 110-111), where they draw attention to the fact that Tolkien virtually paraphrases The Oxford English Dictionary on this subject; and cite a revision to the essay that Tolkien later omitted: "I propose to use Fantasy $\phi \alpha \nu \tau \alpha \sigma \iota \alpha$ a making visible to the mind of the operation whereby mental images of 'things not actually present' are expressed, shown forth, created. The faculty of conceiving images is properly called Imagination.” See also Gilliver, p. $125 \mathrm{ff}$.

${ }^{22}$ A fragment of the poem cited in Tolkien, “On Fairy-stories”, p. 65.
} 
from the drab blur of triteness or familiarity.” (“On Fairy-stories”, pp. 67-68) ${ }^{23}$ We need Recovery from the tyranny of the familiar, "the things which once attracted us by their glitter, or their colour, or their shape, and we laid hands on them, and then locked them in our hoard, acquired them, and acquiring ceased to look at them." (“On Fairy-stories”, p. 67)

We are like dragons who sit on what has become a useless treasure hoard. How can we recover our humanity? Simply, says Tolkien.

Creative fantasy...may open your hoard and let all the locked things fly away like cage-birds. The gems of all turn into flowers or flames, and your will be warned that all you had (or knew) was dangerous and potent, not really effectively chained, free and wild; no more yours than they were you. The 'fantastic' elements...help in this release. (“On Fairy-stories”, p. 68) ${ }^{24}$

The third use, Escape, is related to Recovery, and "is one of the main functions of fairy-stories." This usually elicits charges (with a "tone of scorn or pity") that fantasy literature is merely escapism, but "Why," Tolkien asks, "should a man be scorned if, finding himself in prison, he tries to get out and go home?... Why should we not escape...? ("On Fairy-stories”, pp. 69-70) ${ }^{25}$ Why not, indeed. "In what the misusers are fond of calling Real Life," Tolkien wrote, "Escape is evidently as a rule very practical and may even be heroic." ("On Fairy-stories", p. 69) $)^{26}$

${ }^{23}$ See Robinson; as well as Lewis, Silver Chair, p. 27: "Here on the mountain, the air is clear and your mind is clear; as you drop down into Narnia, the air will thicken. Take great care that it does not confuse your mind.”

${ }^{24}$ This passage uncovers part of the reason for Tolkien's surprising appeal to the hippy generation of the 1960s.

${ }^{25}$ Robert Rorabeck amplifies: "Too often the realm of faerie is ignored or discarded by scholars as escapism not relevant to the primary world of literary study. What Tolkien shows and what is the specific focus of his essay On Fairy-Stories, is that the realm of faerie or fantasy does have immediate relevance to the primary world. Tolkien, endeavoring in two fields of writing, the scholarly and the fictional, provides such a connection: his scholarly work is directly applicable to his sub-created world of Middleearth.” Rorabeck, p. 19. Compare James, “Tolkien, Lewis”, pp. 62-78.

${ }^{26}$ Escape, by the way, is not a shrinking from death, despite the "deepest desire, the Great Escape: the Escape from Death....Death is the theme that most inspired George MacDonald.” pp. 74-75. See also Tolkien, “Mythopoeia,” in Tree and Leaf, p. 100: "They have seen Death and ultimate defeat, and yet they would not in despair retreat, but oft to victory have turned the lure and kindled hearts with legendary fire.” In a draft of letter to Joanna de Bortadano in April 1956, Tolkien wrote that the "real theme" of The Lord of the Rings was "Death and Immortality." (Tolkien, Letters, p. 246); and in another letter in April of 1958, he wrote "Though it is only in reading the work myself...that I become aware of the dominance of the theme of Death. (Not that there is 
This leads to the fourth and final function of Faërie-stories, Consolation, especially "the Consolation of the Happy Ending." One can do no better than to let Tolkien speak for himself here in extenso:

Almost I would venture to assert that all complete fairy-stories must have it [Consolation]....I will call it Eucatastrophe. ${ }^{27}$ The eucatastrophic tale is the true form of fairy-tale, and its highest function. The consolation of fairy-stories, the joy of the happy ending: or more correctly of the good catastrophe, the sudden joyous 'turn' (for there is no true end to any fairy-tale): this joy, which is one of the things which fairy-stories can produce supremely well, is not essentially 'escapist' nor 'fugitive'. In its fairy-tale—or otherworld—setting, it is a sudden and miraculous grace never to be counted on to recur. It does not deny the existence of dyscatastrophe, of sorrow and failure: the possibility of these is necessary to the joy of deliverance; it denies (in the face of much evidence, if you will) universal final defeat and in so far is evangelium, giving a fleeting glimpse of Joy, Joy beyond the walls of the world, poignant as grief. In such stories when the sudden 'turn' comes we get a piercing glimpse of joy, and heart's desire, that for a moment passes outside the frame, rends indeed the very web of story, and lets a gleam come through...

(“On Fairy-stories”, pp. 75-76)

any original 'message' in that: most of human art and thought is similarly preoccupied.) But certainly Death is not an Enemy!” (Tolkien, Letters, p. 267). The index to the letters has dozens of references to "Mortality, in Tolkien's mythology," p. 484.

${ }^{27}$ A word invented by Tolkien. He relates in a letter to Christopher Tolkien, November 7-8, 1944 (Tolkien, Letters, pp. 100-101), that at a Catholic Mass he had been "deeply moved, and had that peculiar emotion we all have-though not often. It is quite unlike any other sensation. And all of a sudden I realized what it was: the very thing that I have been trying to write about and explain-in that fairy-story essay...For it I coined the word 'eucatastrophe': the sudden happy turn in a story which pierces you with a joy that brings tears (which I argued it is the highest function of fairy-stories to produce). And I was there led to the view that it produces its peculiar effect because it is a sudden glimpse of Truth....I concluded by saying that the Resurrection was the greatest 'eucatastrophe' possible in the greatest Fairy-story.... Of course I do not mean that the Gospels tell what is only a fairy-story; but I do mean very strongly that they do tell a fairy-story: the greatest...since the author...is the supreme Artist and the Author of Reality....” This experience led him to conclude, "aloud with absolute conviction: 'But of course! Of course that's how things really do work'. 


\section{Conclusion}

This completes our summing up of Tolkien's responses to three questions: 1 . “What is Faërie?” 2. "What are Faërie and Faërie-stories not?” And lastly, 3. "What is the use of Faërie and Faërie-stories?" In the end, however, Tolkien's ideas on Faërie and Faërie-stories can and will never be fully and completely understood. In the words of Verlyn Flieger and Douglas Anderson: this is

not Tolkien's concluding word on fairies nor on Faërie nor on enchantment. There is probably no single, ultimate summing-up. It seems safe to say that Tolkien never really stopped thinking about fairy-stories or writing fairy-stories or trying to set down on paper all that he felt and thought about the relationship between the real and the imaginative, the sensory and the super-sensory levels of experience. (“On Fairy-stories”, pp. 157-158)

Fantasy, Recovery, Escape, Consolation: all of these make Faërie and Faëriestories well-worth the investment of our time, the effort of our minds, and the meditation of our hearts.

However, there is more to Tolkien's essay on fairy-stories. As Bilbo's song has it: "The Road goes ever on and on, Out from the door where it began. Now far ahead the Road has gone, Let others follow it who can!” (Tolkien, Lord of the Rings, p. 987) Tolkien, shockingly, asks us to go further, much much further. On the surface, Tolkien didn't seem preoccupied with making religion apparent in his work. Indeed, in his last word on Faërie, in "Smith of Wootton Major," he wrote:

... (as in my stories generally) it will be observed that there is no religion. There is no church or temple. Among the professions there is no parson or priest...In a story written by a religious man this is a plain indication that religion is not absent but subsumed: the tale is not about religion or in particular about its relations to other things. It does not therefore appear as such... BUT Faery is not religious. It is fairly evident that it is not Heaven or Paradise... Faery might be said indeed to represent Imagination (without definition because taking in all the definitions of this word): esthetic: exploratory and receptive; and artistic; inventive, dynamic, (sub)creative... (Tolkien, Smith of Wootton Major , pp. 99-101) ${ }^{28}$

\footnotetext{
${ }^{28}$ This is born out elsewhere in his correspondence: writing in draft letter of September 1954 to a reader, Tolkien notes that "There are thus no temples or 'churches' or fanes in this world...They had little or no 'religion' in the sense of worship...” (Tolkien, Letters, p. 193); and in a letter sent to his American publisher, Houghton Mifflin, in June 1955, he wrote: "The only criticism that annoyed me was one that it 'contained no religion (and 'no Women', but that does not matter, and is not true anyway. It is a monotheistic world of 'natural theology'. The odd fact that there are no churches, temples, or religious rites
} 
In a 1953 letter to a close friend, and Roman Catholic priest, Robert Murray, Tolkien wrote:

The Lord of the Rings is of course a fundamentally religious and Catholic work; unconsciously so at first, but consciously in the revision. That is why I have not put in, or have cut out, practically all references to anything like 'religion', to cults or practices, in the imaginary world. For the religious element is absorbed into the story and the symbolism.

(Tolkien, Letters, p. 172) ${ }^{29}$

However, in the "Epilogue" added to "On Fairy-stories" in 1947, Tolkien clearly, beautifully, strikingly, and unmistakably sets forth the religious foundations of his deeply Christian worldview: ${ }^{30}$

The peculiar quality of the 'joy' in successful Fantasy can thus be explained as a sudden glimpse of the underlying reality or truth. It is not only a 'consolation' for the sorrow of this world, but a satisfaction...I would venture to say that approaching the Christian Story from this direction, it has long been my feeling (a joyous feeling) that God redeemed the corrupt making-creatures, men, in a way fitting to this aspect....The Birth of Christ is the eucatastrophe of Man's history. The Resurrection is the eucatastrophe of the story of the Incarnational. This story begins and ends in joy....Art has been verified. God is the Lord, of angels and of men — and of elves. Legend and History have met and fused.

(“On Fairy-stories”, pp. 77-78)

But that's not all. Tolkien goes on to proclaim that

and ceremonies, is simply part of the historical climate depicted....I am in any case myself a Christian, but the 'Third Age' was not a Christian world." (Tolkien, Letters, p. 220). See the index, p. 489, under "Religion, in Tolkien's mythology," for numerous other references.

${ }^{29}$ Tolkien, Letters, 2000, p. 172.

${ }^{30}$ The fact that these thoughts appear in an "Epilogue" may have been responsible for their being generally overlooked. However, as should be clear, this is no mere epilogue, but a central focus of the entire fairy-stories essay. That Tolkien had been thinking about these things for a long time is born out in a letter from C.S. Lewis to Arthur Greeves, of October 18, 1931 (Lewis, The Collected Letters, pp. 976-977): "Now what Dyson and Tolkien showed me was this: that if I met the idea of sacrifice in a Pagan story I didn't mind it at all...in Pagan stories I was prepared to feel the myth as profound and suggestive of meanings beyond my grasp even tho' I could not say in cold prose 'what it meant'. Now the story of Christ is simply a true myth: a myth working on us in the same way as the others, but with this tremendous difference that it really happened...” 
...in God's kingdom the presence of the greatest does not depress the small. Redeemed man is still man. Story, fantasy, still go on, and should go on. The Evangelium has not abrogated legends; it has hallowed them, especially the 'happy ending' [the Eucatastrophe]. The Christian has still to work, with mind as well as body, to suffer, hope, and die, but he may now perceive that all his bents and faculties have a purpose, which can be redeemed. So great is the bounty with which he has been treated that he may now, perhaps, fairly dare to guess that in Fantasy he may actually assist in the effoliation and multiple enrichment of creation. All tales may come true, and yet, at the last, redeemed, they may be as like and as unlike as the forms that we give them as Man, finally redeemed, will be like and unlike the fallen that we know.

(“On Fairy-stories”, pp. 78-79)

That will be the Great Eucatastrophe, "a far-off gleam or echo of evangelium in the real world," (“On Fairy-stories”, p. 77) using Fantasy, Faërie, and Faëriestories as a path to understanding "the mystery of Godliness" and the Incarnation that Paul writes so movingly about in 1 Timothy 3:15-16. ${ }^{31}$ Or, in the words of Tolkien's key poem "Mythopoeia":

Then looking on the Blessed Land 'twill see

that all is as it is, and yet made free:

Salvation changes not, nor yet destroys,

garden nor gardner, children nor their toys....

In Paradise they look no more awry;

and though they make anew, they make no lie....

there each shall choose for ever from the All."

(Tolkien, Tree and Leaf, p. 101)

Let's continue the adventure together. Let us join with Tolkien, Lewis, and kindred spirits in the Great Dance.

\section{Works Cited}

Auden, W. H. Afterword to George MacDonald, The Golden Key, with pictures by Maurice Sendak and an afterword by W. H. Auden. New York: Sunburst Books Edition, 1984. 81-83. Print.

Barfield, Owen. Poetic Diction. A Study in Meaning. London: Faber and Faber, 1928. Print.

Caldecott, Stratford. The Power of the Ring. The Spiritual Vision behind The Lord of the Rings and The Hobbit, revised and expanded edition. New York: Crossroad Publishing, 2012. Print.

\footnotetext{
31. One of the earliest credos of the Church: "Great indeed, we confess, is the mystery of godliness, manifested in the flesh, vindicated by the Spirit..." English Standard Version.
} 
Carpenter, Humphrey. The Inklings. C.S. Lewis, J.R.R. Tolkien, Charles Williams, and their friends. Boston: Houghton Mifflin, 1979. Print.

Duriez, Colin. Tolkien and C.S. Lewis. The Gift of Friendship. Mahwah NJ: Hidden Spring, 2003. Print

Flieger, Verlyn. “Faërie: Tolkien’s Perilous Land,” Tolkien. Maker of Middle-earthEd. Catherine MacIlwaine. Oxford: Bodleian Library, 2018. 35-44. Print.

---. There Will Always be a Fairy Tale: More Essays on Tolkien. Kent OH: Kent StateUniversity Press, 2017. Print.

---. Green Suns and Faërie: Essays on Tolkien. Kent OH: Kent State University Press, 2012. Print.

---. A Question of Time. J.R.R. Tolkien's Road to Faërie. Kent OH: Kent State University Press, 1997. Print.

Gilliver, Peter, Jeremy Marshall, and Edmund Weiner, The Ring of Words. Tolkien and the Oxford English Dictionary. Oxford: Oxford University Press, 2006. Print.

Jacobs, Alan. The Narnian. The Life and Imagination of C.S. Lewis. San Francisco: HarperSanFrancisco, 2005. Print.

James, Edward. "Tolkien, Lewis and the explosion of genre fantasy," The Cambridge Companion to Fantasy Literature. Ed. Edward James and Farah Mendlesohn Cambridge: Cambridge University Press, 2012. 62-78. Print.

Keating, Keating. "Sub-creation in Tolkien and Sayers. Reflections from a Theologian," The C.S. Lewis Chronicle. 3. 2 (2006). 11-20. Print.

Kilby, Clyde S. The Arts and the Christian Imagination. Essays on Art, Literature, and Aesthetics. Ed. William Dyrness and Keith Call. Brewster MA: Mount Tabor Books, Paraclete Press, 2016. 12-105; 106-133. Print.

---. A Well of Wonder. Essays on C.S. Lewis, J.R.R. Tolkien, and the Inklings. Ed. Loren Wilkinson and Keith Call. Brewster MA: Mount Tabor Books, Paraclete Press, 2016. 241 253. Print.

Lewis, Clive Staples. The Collected Letters of C.S. Lewis, Vol. I: Family Letters 19051931. Ed. Walter Hooper. San Francisco: HarperSanFrancisco, 2004. Print.

---. The Silver Chair New York: Harper Trophy Edition, 2000. Print.

---. The Abolition of Man. San Francisco: HarperOne, 2000. Print.

---. On Stories and Other Essays on Literature. Ed. Walter Hooper. New York: Harcourt Harvest Books, 1982. Print.

---. English Literature in the Sixteenth Century excluding Drama. London: Oxford University Press, 1954. Print.

MacDonald, George. Lilith. Introduction by Lin Carter. New York: Ballantine Books, 1969. Print.

McGrath, Alister E. The Intellectual World of C.S. Lewis. Oxford: Wiley-Blackwell 2014. Print.

Michelson, Paul E. “The Development of J.R.R. Tolkien's Ideas on Fairy-stories.” Inklings Forever 8 (2012): 115-127. Print.

---. “George MacDonald and J.R.R. Tolkien on Faërie and Fairy Stories.” Inklings Forever 9 (2014): 92-101. Print.

Pezzini, Giuseppe. "The Authors of Middle-Earth: Tolkien and the Mystery of Literary Creation.” Journal of Inklings Studies. 8.1 (2018). 31-64. Print. 
Prickett, Stephen. Victorian Fantasy, second revised and expanded edition. Waco TX: Baylor University Press, 2005. Print.

---. Narrative, Religion, and Science. Fundamentalism versus Irony, 1700-1999. Cambridge: Cambridge University Press, 2002. Print.

Purtill, Richard. J.R.R. Tolkien. Myth, Morality, and Religion. San Francisco: Ignatius Books, 2003. Print.

Robinson, John. "Faërie in J.R.R. Tolkien and C.S. Lewis: Escape vs. Recovery," The Chronicle of the Oxford University C.S. Lewis Society. 5.2 (2008). 4-21. Print.

Rorabeck, Robert. Tolkien's Heroic Quest. Kent UK: Crescent Moon Press, 2008. Print.

Sayers, Dorothy L. The Mind of the Maker. New York: Meridian Books, 1956. Print.

Shippey, T. A. The Road to Middle-earth, revised and expanded edition. Boston: Houghton Mifflin, 2003. Print.

---. J.R.R. Tolkien. Author of the Century. Boston: Houghton Mifflin, 2000. Print.

Thorson, Stephen, Joy and Poetic Imagination. Understanding C.S. Lewis's 'Great War' with Owen Barfield and its Significance for Lewis's Conversion and Writings. Hamden CT: Winged Lion Press, 2015. Print.

Tolkien, J.R.R. Tolkien on Fairy-stories. Expanded edition with commentary and notes. Ed. Verlyn Flieger and Douglas A. Anderson. London: HarperCollins, 2008 Print.

---. Tales of the Perilous Realm. Introduction by Tom Shippey, and illustrations and an afterword by Alan Lee. Boston: Houghton Mifflin Harcourt, 2008. Print.

---. Smith of Wootton Major, enlarged edition. Ed. Verlyn Flieger. London: HarperCollins, 2005. Print.

---. The Lord of the Rings. Fiftieth Anniversary (Third) Edition. Ed. by Christopher Tolkien with a note on the text by Douglas A. Anderson and a note on the $50^{\text {th }}$ anniversary edition by Wayne G. Hammond and Christina Scull. Boston: Houghton Mifflin, 2004. Print.

---. The Letters of J.R.R. Tolkien. Expanded edition. Ed. by Humphrey Carpenter with the assistance of Christopher Tolkien. Boston: Houghton Mifflin, 2000. Print

---. Tree and Leaf including the poem Mythopoeia, second edition. Ed. with an introduction by Christopher Tolkien. London: Unwin Hyman, 1988. Print.

---. “On Fairy-stories.” Rpt. in J.R.R. Tolkien, The Monsters and the Critics and OtherEssays. Ed. with a foreword by Christopher Tolkien. London: George Allen and Unwin, 1983. 109-161. Print.

---. “On Fairy-stories.” Rpt. in J.R.R. Tolkien, The Tolkien Reader. New York: Ballantine Books, 1966. 3-84. Print.

---. “On Fairy-stories.” Rpt. in J.R.R. Tolkien, Tree and Leaf. London: George Allen and Unwin, 1964. 11-70. Print.

---. “On Fairy-stories.” Rpt. in Essays presented to Charles Williams. Ed. C.S. Lewis. London: Oxford University Press, 1947). 38-89. Print.

Wilson, Edmund, “Oo, Those Awful Orcs!” The Nation. 182 (1956), 312-313. Rpt. in Book of the Month Club, A Reader's Companion to The Hobbit and The Lord of the Rings. New York: Quality Paperback Book Club, 1995. 55-63. Print. 
Paul E. Michelson is Distinguished Professor of History Emeritus at Huntington University, where he began teaching in 1974. He has been three times a Fulbright fellow in Romania (1971-1973, 1982-1983, 1989-1990). His book, Romanian Politics, 1859-1871: From Prince Cuza to Prince Carol (1998) was awarded the 2000 Bălcescu Prize for History by the Romanian Academy. His areas of interest and expertise include historiography, Romanian history in the $19^{\text {th }}-21^{\text {st }}$ centuries, Totalitarian and post-Totalitarian societies, the History of Venice, and the works of C.S. Lewis and J.R.R. Tolkien. He is the author, editor, or co-editor of six books and over 150 articles. He is past President and Secretary of the Society for Romanian Studies and served as the Secretary of the Conference on Faith and History.

Email: pmichelson@huntington.edu 
